\title{
Effects of Holocene climate change on the historical demography of migrating sharp-shinned hawks (Accipiter striatus velox) in North America
}

\author{
JOSHUA M. HULL*+ and DEREK J. GIRMAN* \\ *Department of Biology, Sonoma State University, 1801 East Cotati Avenue, Rohnert Park, CA 94928-3609, USA; +Golden Gate \\ Raptor Observatory, Building 201 Fort Mason, San Francisco, CA 94123, USA
}

\begin{abstract}
DNA sequences of the mitochondrial control region were analysed from 298 individual sharpshinned hawks (Accipiter striatus velox) sampled at 12 different migration study sites across North America. The control region proved to be an appropriate genetic marker for identification of continental-scale population genetic structure and for determining the historical demography of population units. These data suggest that sharp-shinned hawks sampled at migration sites in North America are divided into distinct eastern and western groups. The eastern group appears to have recently expanded in response to the retreat of glacial ice at the end of the last glacial maximum. The western group appears to have been strongly effected by the Holocene Hypsithermal dry period, with molecular evidence indicating the most recent expansion following this mid-Holocene climatic event 7000-5000 years before present.
\end{abstract}

\section{Introduction}

Changes in the distribution of species through recent geological time have long been of interest to ecologists. For example, Davis (1969) examined variation in a New England forest community through the Holocene and found a strong effect of climatic change during this period. The abundance of fossil pollen has made examination of changes in terrestrial plant distributions through time easier to address than similar studies of animals, which have often left a scant fossil record. With advances in molecular genetic methods, techniques have become available that allow ecologists to investigate how the distributions of animal species may have changed in response to climatic events in recent geological history (Avise \& Walker 1998; Douglas et al. 2003). Many studies have focused on speciation events related to the Pleistocene Refugia Hypothesis, wherein a series of glaciations followed by glacial retreat and habitat recovery was proposed to potentially account for patterns of avian species diversity across North America (Klicka \& Zink 1997).
Pleistocene refugia have been suggested to also explain much of the current population structure within species. For example, molecular studies of North American migratory bird species have revealed genetic differentiation between eastern and western subspecies or populations (divided by the Great Plains and Rocky Mountains) (Milot et al. 2000; Kimura et al. 2002). Analyses of historical demography in avian species have suggested that populations were isolated during glacial maxima and subsequently expanded into their present ranges in response to retreat of glacial ice, approx. 16000 years before present (ybp), and the concurrent recovery of suitable habitat during interglacial periods (Merilä et al. 1997; Mila et al. 2000; Peck \& Congdon 2004).

Climatic factors associated with the Hypsithermal period (7000-5000 bp) may also have had a profound effect on the distribution of some North American species. The Hypsithermal period appears to have been a time of rapid climate change. Stable isotope ratios of deuterium, analysis of atmospheric $\mathrm{CO}_{2}$ taken from Antarctic ice core samples, and fossil pollen records indicate that the global Hypsithermal climate was more arid, causing a prolonged drought throughout western North America (Steig 1999). This period has been implicated in historic changes observed in the 
distribution of a variety of North American plant taxa (Davis 1969) and nonavian vertebrates (Webb 1984; Douglas et al. 2003).

In this paper, we examined population structure and historical demography of sharp-shinned hawks (Accipiter striatus) to test hypotheses about the impacts of climatic events associated with Pleistocene and Hypsithermal periods. First, we tested whether sharp-shinned hawk populations were partitioned in an east-west manner similar to other avian species. Sharp-shinned hawks banded during migration through western North America have been subsequently recovered only within western regions during both migration and the breeding season (Hoffman et al. 2002; Hull 2003). A similar pattern has been observed in sharp-shinned hawks migrating in eastern North America (Clark 1985). These patterns, along with strong fidelity to breeding ground observed in the closely related European sparrowhawk (Accipiter nisus) (Newton 1979), provided a priori support for the hypothesis that North American sharp-shinned hawks likely display an east-west genetic subdivision.

Second, we examined historical demography to determine whether populations had recently expanded, as has been found in other North American species, and, if so, how long ago such expansions occurred. Established paradigms regarding the continental scale genetic structure and historical demography in birds have been built largely on studies of songbird or seabird species which, to date, have not been found to be affected by the Hypsithermal (Klicka \& Zink 1997; Kidd \& Friesen 1998; Congdon et al. 2000; Mila et al. 2000). In contrast, because of their reliance on dense conifer stands with younger trees (Rosenfield et al. 1991), sharpshinned hawks provide a model for species whose populations may have been particularly sensitive to arid conditions prevalent during the Hypsithermal. Consequently, we might expect to find a demographic effect associated with the Hypsithermal in this species. We analysed mitochondrial DNA sequence data from the control region to investigate these questions.

\section{Materials and methods}

\section{Sampling}

Feathers were analysed from 12 sampling sites associated with migratory routes from across North America: Bonney Butte, Oregon, USA (OR, $n=29)$; Sausalito, California, USA (CA, $n=31$ ); Boise, Idaho, USA (ID, $n=35)$; Goshutes, Nevada, USA (NV, $n=27)$; Manzano Mountains, New Mexico, USA (NM, $n=24)$; Hawk Cliff, Ontario, Canada (ON, $n=23)$; Hawk Ridge, Minnesota, USA (MN, $n=21$ ); Cedar Grove, Wisconsin, USA (WI, $n=20)$; Cape May Point, New Jersey, USA (NJ, $n=21$ ); Little Gap, Pennsylvania, USA (PA, $n=24)$; Wise Point, Virginia, USA (VA, $n=20$ ); La Mancha, Veracruz, Mexico (VC, $n=20)$. Mist nets, bow nets, and dho ghazzas (a square $2 \mathrm{~m} \times 2 \mathrm{~m}$ net) were used to capture individuals at each site. Two contour feathers were plucked from the breast of each individual, approximately $2 \mathrm{~cm}$ below the crop. Samples were collected between August 15, 1999, and October 15, 1999, during peak sharp-shinned hawk migration. Ten or fewer individuals were sampled per site in any 1-week period to avoid over-representing certain latitudes.

\section{Data generation}

DNA extraction was performed following the Qiagen DNeasy protocol for animal tissues (Qiagen). Polymerase chain reaction (PCR) was used to isolate and amplify portions of the mitochondrial genome (Saiki et al. 1980). Owing a novel rearrangement in the position of the control region within the mitochondrial genome of Accipitriidae, we used an atypical combination of primers to amplify a portion of the control region (Haring et al. 2001). Primer Thr16064, which flanks the control region on the $5^{\prime}$ end, and primer CR537, which is approximately 600 bp downstream from Thr16064, were used for all samples (Sorenson et al. 1999). Double-stranded PCR products were generated in $50-\mu \mathrm{L}$ reactions consisting of buffer $(100 \mathrm{~mm}$ Tris- $\mathrm{HCl}$, $\mathrm{pH}$ 9.0, $500 \mathrm{~mm} \mathrm{KCl}, 1 \%$ Triton X-100), $2.5 \mathrm{~mm} \mathrm{MgCl}_{2}$, $0.8 \mathrm{~mm}$ dNTPs, $0.1 \mathrm{~mm}$ of each primer, 1.25 units of Taq DNA polymerase (Promega), 20-60 ng of genomic DNA in an MJ Research thermocycler. The PCR parameters were 1 cycle of $95^{\circ} \mathrm{C}$ for $2 \mathrm{~min}, 34$ cycles of $94^{\circ} \mathrm{C}$ for $30 \mathrm{~s}, 53^{\circ} \mathrm{C}$ for $45 \mathrm{~s}$ and $72{ }^{\circ} \mathrm{C}$ for $1 \mathrm{~min}$, and 1 cycle of $72{ }^{\circ} \mathrm{C}$ for $10 \mathrm{~min}$.

We also conducted a preliminary cytochrome $b$ analysis on a subset of samples. We used universal primers (LCBOB and HCBETY) developed in previous studies (Outlaw et al. 2003). The PCR parameters for cytochrome $b$ amplification were 1 cycle of $95^{\circ} \mathrm{C}$ for $2 \mathrm{~min}, 34$ cycles of $94^{\circ} \mathrm{C}$ for $30 \mathrm{~s}$, $48^{\circ} \mathrm{C}$ for $30 \mathrm{~s}$, and $72{ }^{\circ} \mathrm{C}$ for $1 \mathrm{~min}$, and 1 cycle of $72{ }^{\circ} \mathrm{C}$ for $10 \mathrm{~min}$.

The PCR products were run in low-melt agarose gels, excised, and subsequently isolated using an UltraClean DNA Purification Kit (MoBio Laboratories). They were used in a cycle sequencing reaction using a Thermo Sequenase fluorescent labelled cycle sequencing kit with 7-deaza-dGTP from Amersham Pharmacia and run in a 5\% acrylamide gel in a Li-Cor Gene ReadIR 4200 automated sequencer. Sequences were examined and aligned by eye using the program SEQUENCHER (Gene Codes Corporation).

\section{Data analysis}

Relationships among sharp-shinned hawk mtDNA control region sequences were analysed using three approaches. The relationships of the genotypes were first estimated by unweighted maximum parsimony analysis using PAUP* version 4.0 (Swofford 2003) with Accipiter nisus as an 
outgroup. Accipiter nisus was used as an outgroup based on previous morphological studies, studies of DNA-DNA hybridization, and unpublished analyses of the cytochrome b gene (Wattel 1973; Sibley \& Ahlquist 1991; J. M. Hull unpublished). The strength of each node was assessed using 1000 bootstrap replicates. Second, the genetic distances among control region nucleotide sequences were estimated using the Tamura-Nei model, which estimates the differential rates of transitional substitution between purines and between pyramidines and the proportion of transversional differences (Tamura \& Nei 1993). Genetic distances were used to construct neighbour-joining trees in PAUP* 4.0 (Swofford 2003). Finally, we generated minimumspanning networks, in which haplotypes are the nodes of a network rather than the terminal tips of a tree. All possible minimum spanning networks were determined using pairwise absolute distances generated in ARLEQUIN (Schneider et al. 1997).

To examine differences among localities, average sequence divergence among sampling sites was computed (Nei 1987). Estimates of mean sequence divergence between populations $\left(p_{\mathrm{A}}\right)$ were corrected for polymorphisms within each population (Nei 1987). The resulting divergence matrix was used, with a neighbour-joining algorithm, to make a clustering tree using the program PHYLIP (Felsenstein 1989).

The significance of geographical divisions among sample sites was evaluated by estimating $\Phi_{\mathrm{ST}}$, the proportion of total genetic variation attributable to among-site variation vs. within-site variation using the program ARLEQUIN version 2.0 (Schneider et al. 1997). Pairwise estimates of $\Phi_{\mathrm{ST}}$ were used to estimate subdivision among all sampling locations.

Population groupings were analysed using an analysis of molecular variance (AMOvA) (Excoffier et al. 1992). This method was used because, unlike other $F_{\mathrm{ST}}$ analogues, it is not sensitive to deviations from a normal distribution of genotypes (Takahata \& Palumbi 1985; Hudson et al. 1992). Groupings tested were identified on the basis of the pattern of geographical occurrence of haplotypes, the pattern of average sequence divergence among populations, and biogeographical proximity of sampling sites. Those groupings that maximized values of $\Phi_{\mathrm{CT}}$ in an analysis of molecular variance (AMOVA) and were significantly different from distributions of individuals generated from 1000 random permutations of the DNA sequences should reflect the most probable geographical subdivisions (Excoffier et al. 1992).

Historical demography was inferred through a variety of methods. First, nucleotide diversity $(\pi)$ and haplotype diversity (h) (Nei 1987) within all groups along with pairwise differences were calculated using the program ARLEQUIN (Schneider et al. 1997). Comparing haplotype diversity and nucleotide diversity can reveal information about patterns of historical demography. High haplotype diversity in conjunction with low nucleotide diversity can suggest recent population growth while high haplotype diversity with high nucleotide diversity is indicative of a longstanding population (Mila et al. 2000). We also calculated an expansion coefficient $(S / d)$ or the ratio of variable sequence positions $(S)$ relative to the mean number of pairwise nucleotide differences $(d)$ between haplotypes (Peck \& Congdon 2004). Recent population expansions are indicated by large values and constant long-term population size is indicated by small values (von Haeseler et al. 1996).

We also investigated historical patterns of population structure using the mismatch distribution of pairwise nucleotide differences in pooled genetically distinct groups with the programs ARLEQUIN version 2.0 and DNASP version 4.00 (Rogers \& Harpending 1992; Schneider et al. 1997; Rozas et al. 2003). If a population has undergone rapid expansion, a unimodal mismatch distribution approximating a Poisson curve is expected (Rogers \& Harpending 1992), whereas populations approaching mutation drift equilibrium are expected to produce a multimodal or 'ragged' mismatch distribution. We examined the 'raggedness' statistic $(r g)$ and assessed the statistical significance of this value from the distribution of the statistic determined by simulations (Harpending et al. 1993).

Statistics based on the mismatch distribution, such as $r g$, are thought to be less robust at detecting expansion, therefore, we also employed a range of neutrality statistics to detect traces of past population growth or stability based on DNA sequences (Ramos-Onsins \& Rozas 2002). Fu's (1997) $F_{S}$ test statistic uses information from the haplotype distribution to test specifically for population growth and has been shown to be among the best statistics for detecting population growth in comparisons of statistical power (Fu 1997; Ramos-Onsins \& Rozas 2002). We used Tajima's (1989) D-test, which contrasts the number of nucleotide differences between sequences $(\pi)$ and the number of differences between segregating sites $(\theta)$. Population expansions can cause significant negative departures of Tajima's D from 0 (Tajima 1989). Fu \& Li's (1993) $D^{*}$ and $F^{*}$ statistics were calculated for comparison with Fu's $F_{S}$. The effects of background selection can be distinguished from population growth or range expansion by examining the pattern of significance between $F_{S^{\prime}} F^{*}$, and $D^{*}$ (Fu 1997). If $F_{\mathrm{S}}$ is significant and $F^{*}$ and $D^{*}$ are not, then population growth or range expansion is indicated, whereas the reverse suggests selection (Fu 1997). All of these calculations were completed using DNASP 4.0 (Rozas et al. 2003).

To estimate time since expansion, we used the mismatch distributions and the nonlinear least-square approach in ARLEQUIN version 2.0 (Schneider et al. 1997). The relationship of $\tau=2 u t$ was used where $t$ is the number of generations elapsed between initial population and current population and $u=2 \mu k$, where $\mu$ is the mutation rate per million years and $k$ is the length of the sequence (Rogers 


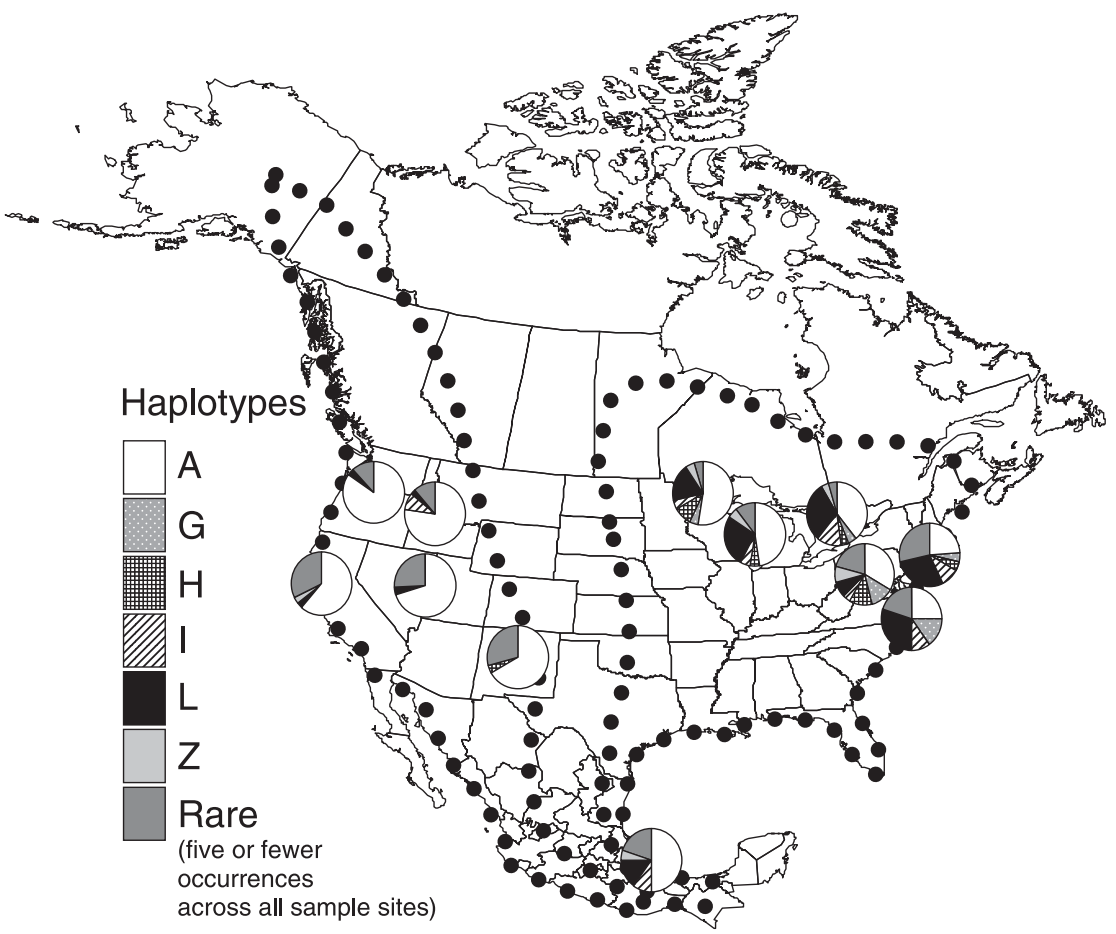

Fig. 1 Map of North American sampling localities (samples collected between August 15,1999 , and October 15, 1999) indicating east-west division (Clark 1985; Hoffman et al. 2002) and frequency of haplotype occurrence at each site. Identification of localities is provided in the text.

1995). This algorithm assumes rather than tests for population expansion, therefore, the time estimate is only valid insofar as the assumption holds.

\section{Results}

\section{Patterns of genetic variation}

We found no variation in cytochrome $b$ sequences among 12 sharp-shinned hawk samples examined from 12 geographically disparate localities, each containing distinct and widely varying control region sequences.

Domain I of the control region displayed considerably more variation within sharp-shinned hawks, with 26 (4.90\%) variable sites of the 531 examined (GenBank accession numbers AY791851-AY791883). Of these 26 variable sites, 23 had transitions and two had transversions. Empirical nucleotide frequencies among all samples were found to be: $A=28.75 \%, C=30.05 \%, G=13.43 \%$ and $T=27.77 \%$. A total of 33 control region haplotypes were identified (Fig. 1, Table 1). Haplotype $A$ was the only one found at all sample localities. Of the remaining 32 haplotypes, 10 occurred among both eastern and western sites, 13 among western sites only (five at multiple western sites), and nine among eastern sites only (four at multiple eastern sites).

Bootstrap analysis of the maximum parsimony tree found no support for differentiation among any ingroup haplotypes (Fig. 2). There was $100 \%$ bootstrap support for $A$. s. velox haplotypes as distinct from $A$. nisus.
Neighbor Joining

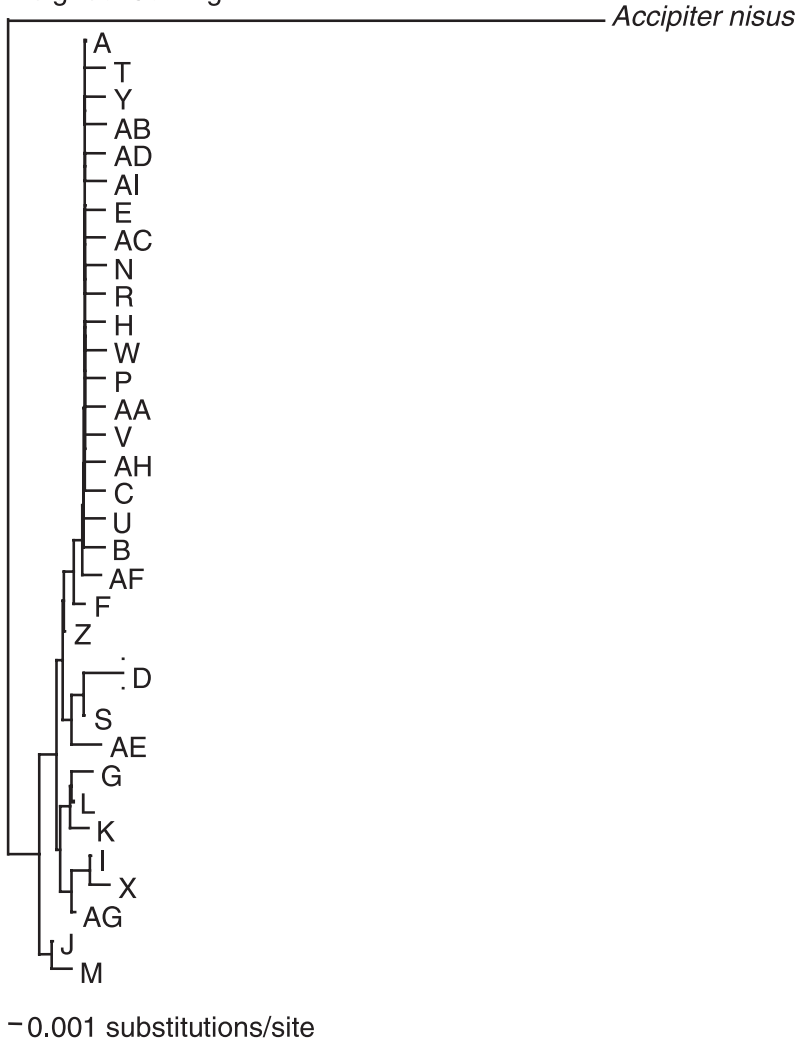

Fig. 2 Neighbour-joining tree from Tamura-Nei distances of control region haplotypes for Accipiter velox sampled in North America with Accipiter nisus as the outgroup (Tamura \& Nei 1993). 
Table 1 Haplotype distribution among 12 sampling localities

\begin{tabular}{|c|c|c|c|c|c|c|c|c|c|c|c|c|}
\hline \multirow[b]{2}{*}{ Haplotype } & \multicolumn{12}{|c|}{ Migration sample sites } \\
\hline & OR & $\mathrm{CA}$ & ID & NV & NM & $\mathrm{ON}$ & $\mathrm{MN}$ & WI & $\mathrm{NJ}$ & PA & VA & $\mathrm{VC}$ \\
\hline A & 22 & 19 & 27 & 19 & 16 & 9 & 11 & 9 & 5 & 8 & 5 & 10 \\
\hline B & & 1 & 1 & 1 & & & & & & & & \\
\hline $\mathrm{C}$ & & 1 & 1 & & 1 & & & & & & & \\
\hline $\mathrm{D}$ & & 1 & & & & & & & & & & 1 \\
\hline E & & 1 & & 1 & & & & & 2 & & & \\
\hline $\mathrm{F}$ & & 1 & & & & & & & & & & \\
\hline G & & & & & & 1 & 1 & & 1 & 3 & 3 & \\
\hline $\mathrm{H}$ & & & & & 1 & 1 & 2 & 1 & 1 & 3 & & \\
\hline I & & & 3 & & & 3 & 1 & 1 & 2 & 1 & 2 & 2 \\
\hline $\mathrm{J}$ & & & & & & & & 1 & 1 & 1 & & \\
\hline K & & & & & & 1 & & & 1 & 1 & & \\
\hline $\mathrm{L}$ & & 1 & & 1 & & 7 & 4 & 5 & 6 & 2 & 6 & 3 \\
\hline $\mathrm{M}$ & & & & & & & & & 1 & & & \\
\hline $\mathrm{N}$ & & & & & & & & & 1 & & & \\
\hline $\mathrm{P}$ & & 1 & & & & & & & & & & 1 \\
\hline $\mathrm{R}$ & 1 & & & & & & & & & & & \\
\hline$S$ & 1 & & 1 & & & & & 1 & & & & 1 \\
\hline $\mathrm{T}$ & 1 & & & 1 & 1 & & & & & & & \\
\hline $\mathrm{U}$ & & 1 & & 1 & & & & & & & & \\
\hline V & & & & 1 & & & & & & & & \\
\hline W & & & & 1 & & & & 1 & & 1 & 1 & 1 \\
\hline$X$ & & & & & & & 1 & & & & & \\
\hline $\mathrm{Y}$ & & 1 & & & 3 & & & & & & & \\
\hline $\mathrm{Z}$ & 1 & 1 & 1 & & & 1 & 1 & 1 & & 2 & & 1 \\
\hline AA & & 1 & & & & & & & & & & \\
\hline $\mathrm{AB}$ & & 1 & & & & & & & & & & \\
\hline $\mathrm{AC}$ & & & & & 1 & & & & & & & \\
\hline $\mathrm{AD}$ & & & & 1 & & & & & & & & \\
\hline $\mathrm{AE}$ & & & 1 & & & & & & & & & \\
\hline $\mathrm{AF}$ & & & & & 1 & & & & & 1 & & \\
\hline AG & & & & & & & & & & 1 & 1 & \\
\hline $\mathrm{AH}$ & & & & & & & & & & & 1 & \\
\hline AI & & & & & & & & & & & 1 & \\
\hline
\end{tabular}

Sampling sites: OR, Bonney Butte, Oregon, USA $(n=29)$; CA, Sausalito, California, USA $(n=31)$; ID, Boise, Idaho, USA ( $n=35)$; NV, Goshutes, Nevada, USA ( $n=27)$; NM, Manzano Mountains, New Mexico, USA $(n=24)$; ON, Hawk Cliff, Ontario, Canada ( $n=23)$; MN, Hawk Ridge, Minnesota, USA $(n=21)$; WI, Cedar Grove, Wisconsin, USA $(n=20)$; NJ, Cape May Point, New Jersey, USA ( $n=21)$; PA, Little Gap, Pennsylvania, USA $(n=24)$; VA, Wise Point, Virginia, USA $(n=20)$; VC, La Mancha, Veracruz, Mexico $(n=20)$.

Analysis of mean sequence divergence among sampling sites was used to create an average sequence divergence tree (Fig. 3). This tree supports an east-west division among migration sites. Eastern sites were distinct from western sites and were separated from each other by larger genetic distances than sites within the western region. Western sites were more tightly grouped and separated from each other by lower levels of genetic distance. The VC site is near the centre of the network, but appears to have a smaller genetic distance from eastern sites than from western sites.

A minimum spanning network of haplotypes also suggested a difference in haplotype history between East and the West (Fig. 4a). Consideration of minimum spanning networks for eastern and western populations separately (Fig. 4b,c) can yield insight into evolution of the control region in these two geographical areas. In both regions, the strong star-like tree topology suggests a recent population expansion. In the West (Fig. 4b), high frequency and ubiquity of haplotype A suggested that it was the progenitor of most western haplotypes, except for D, I, L, S and AE. The minimum spanning network for the eastern sites (Fig. 4c) displayed more structure, with both haplotype A and haplotype L acting as important progenitors for eastern haplotypes.

Pairwise $\Phi_{\text {ST }}$ comparisons among sites revealed no significant genetic differentiation among eastern sampling sites including the Veracruz sampling locality $(P>0.05$, 


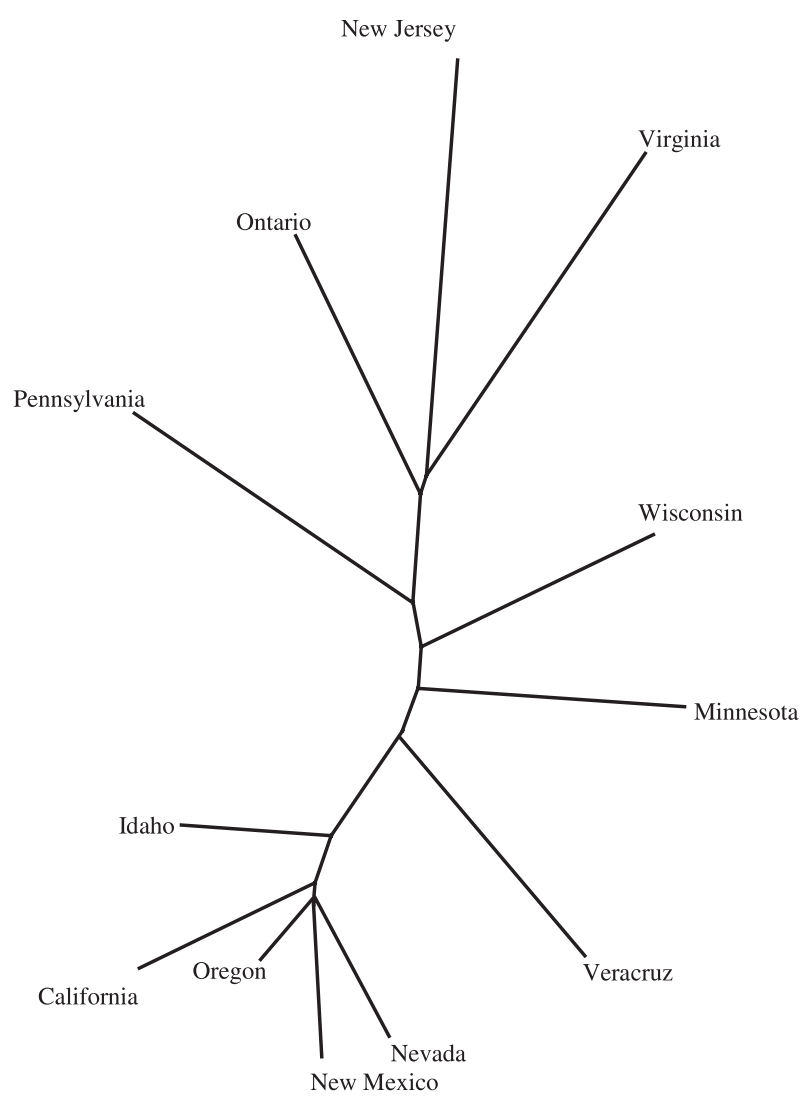

Fig. 3 Neighbour-joining clustering network of sampling localities based on average sequence divergence among sites.

Table 2). In the West, the only significant distinction indicated by pairwise $\Phi_{\text {ST }}$ comparisons was between ID and NM. Except for ID, which was not significantly differentiated from VC or MN, western locations were significantly distinct from all eastern locations. Several groupings of sites were compared with test hypotheses about groupings that might maximize partitioning of genetic variance and, in particular, to sort out the placement of ID, VC and MN. The grouping of sites that displayed highest $\Phi_{\mathrm{CT}}$ value was the West, including OR, CA, ID, NV and NM, and the East, including ON, MN, WI, NJ, PA and VA along with VC $\left(\Phi_{\mathrm{CT}}=0.16895 ; P<0.01\right)$ (Fig. 1). The groupings with next highest support were: a western group containing OR, CA, $\mathrm{NV}, \mathrm{ID}, \mathrm{NM}, \mathrm{MN}$, and $\mathrm{VC}$, and an eastern group containing $\mathrm{ON}, \mathrm{NJ}, \mathrm{PA}, \mathrm{VA}, \mathrm{WI}\left(\Phi_{\mathrm{CT}}=0.10850 ; P<0.01\right)$. All other logically hypothesized groupings based on biogeographical proximity, haplotype distribution among sampling sites, and/ or results of pairwise $\Phi_{\mathrm{ST}}$ analyses gave nonsignificant results, as exemplified by a western group consisting of $\mathrm{OR}, \mathrm{CA}, \mathrm{NV}$ and $\mathrm{NM}$, and an eastern group composed of $\mathrm{ON}, \mathrm{MN}, \mathrm{WI}$, $\mathrm{NJ}, \mathrm{PA}, \mathrm{VA}, \mathrm{VC}$ and ID $\left(\Phi_{\mathrm{CT}}=0.05095 ; P=0.062\right)$.

Analysis of genetic diversity among eastern sites revealed 17 transitions and no transversions in 17 polymorphic sites, a haplotype diversity of 0.793 , a nucleotide diversity



(b)
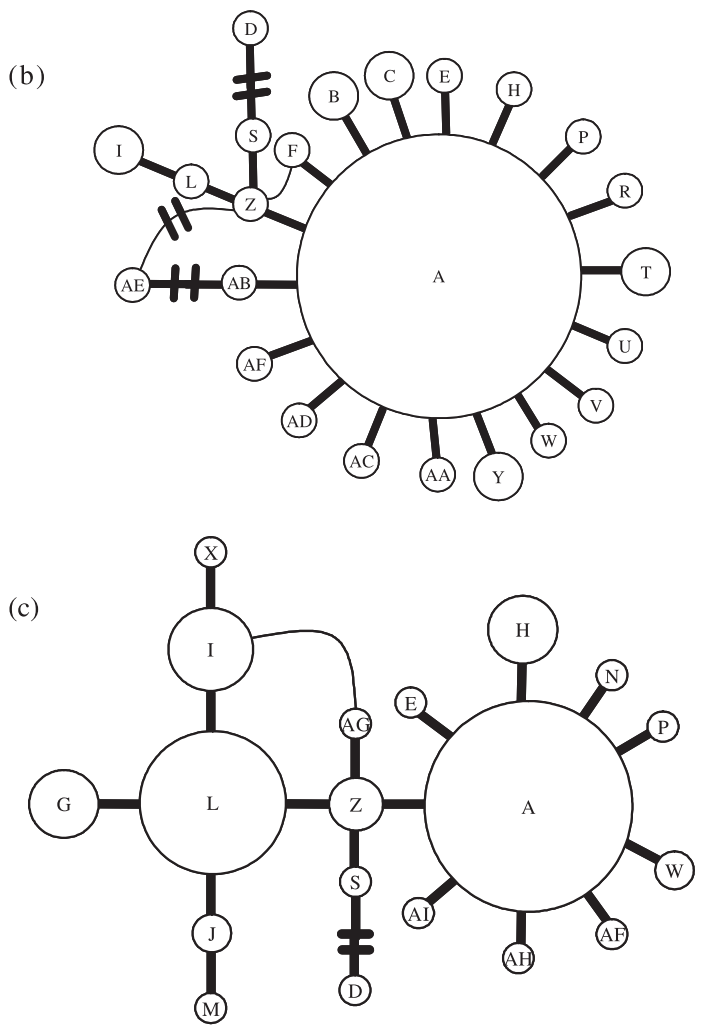

Fig. 4 Minimum spanning networks depicting absolute difference between haplotypes for (a) all sampling localities, (b) western sampling localities only and (c) eastern sampling localities only. The relative abundance of each haplotype is indicated by the sizes of the circles, hash marks indicate the number of base pair changes between haplotypes (a single base pair change is indicated by absence of a hash mark).

of 0.00324 and an average pairwise distance value of 1.72 . In the West, 19 transitions and two transversions were found among 21 polymorphic sites with a haplotype diversity value of 0.473 , a nucleotide diversity of 0.00140 and an average pairwise distance value of 0.741 . Both eastern and western groups demonstrate a classic pattern of high haplotype diversity along with low nucleotide diversity often associated with a recent population expansion. 
Table 2 Pairwise $\phi_{\mathrm{ST}}$ values between sampling sites

\begin{tabular}{|c|c|c|c|c|c|c|c|c|c|c|c|c|}
\hline & OR & CA & ID & NV & $\mathrm{NM}$ & $\mathrm{ON}$ & $\mathrm{MN}$ & WI & NJ & PA & VA & $\mathrm{VC}$ \\
\hline OR & 0.000 & & & & & & & & & & & \\
\hline \multirow[t]{2}{*}{ CA } & -0.013 & & & & & & & & & & & \\
\hline & - & 0.000 & & & & & & & & & & \\
\hline \multirow[t]{2}{*}{ ID } & 0.013 & -0.007 & & & & & & & & & & \\
\hline & - & - & 0.000 & & & & & & & & & \\
\hline \multirow[t]{2}{*}{$\mathrm{NV}$} & -0.011 & -0.011 & 0.016 & & & & & & & & & \\
\hline & - & - & - & 0.000 & & & & & & & & \\
\hline \multirow[t]{2}{*}{ NM } & 0.022 & 0.006 & 0.051 & 0.114 & & & & & & & & \\
\hline & - & - & + & - & 0.000 & & & & & & & \\
\hline \multirow[t]{2}{*}{$\mathrm{ON}$} & 0.353 & 0.259 & 0.215 & 0.323 & 0.353 & & & & & & & \\
\hline & + & + & + & + & + & 0.000 & & & & & & \\
\hline \multirow[t]{2}{*}{$\mathrm{MN}$} & 0.179 & 0.110 & 0.068 & 0.157 & 0.193 & 0.005 & & & & & & \\
\hline & + & + & - & + & + & - & 0.000 & & & & & \\
\hline \multirow[t]{2}{*}{ WI } & 0.215 & 0.132 & 0.095 & 0.191 & 0.233 & -0.006 & -0.036 & & & & & \\
\hline & + & + & + & + & + & - & - & 0.000 & & & & \\
\hline \multirow[t]{2}{*}{ NJ } & 0.333 & 0.250 & 0.220 & 0.304 & 0.333 & -0.032 & 0.020 & 0.002 & & & & \\
\hline & + & + & + & + & + & - & - & - & 0.000 & & & \\
\hline \multirow[t]{2}{*}{ PA } & 0.191 & 0.130 & 0.096 & 0.176 & 0.202 & -0.004 & -0.031 & -0.028 & 0.006 & & & \\
\hline & + & + & + & + & + & - & - & - & - & 0.000 & & \\
\hline \multirow[t]{2}{*}{ VA } & 0.365 & 0.277 & 0.238 & 0.335 & 0.365 & -0.033 & 0.026 & 0.014 & -0.024 & 0.007 & & \\
\hline & + & + & + & + & + & - & - & - & - & - & 0.000 & \\
\hline \multirow[t]{2}{*}{$\mathrm{VC}$} & 0.139 & 0.076 & 0.041 & 0.133 & 0.168 & 0.030 & -0.023 & -0.032 & 0.044 & -0.013 & 0.048 & \\
\hline & + & + & - & + & + & - & - & - & - & - & - & 0.000 \\
\hline
\end{tabular}

Sampling sites: OR, Bonney Butte, Oregon, USA $(n=29)$; CA, Sausalito, California, USA ( $n=31)$; ID, Boise, Idaho, USA ( $n=35)$; NV, Goshutes, Nevada, USA ( $n=27)$; NM, Manzano Mountains, New Mexico, USA $(n=24)$; ON, Hawk Cliff, Ontario, Canada ( $n=23)$; MN, Hawk Ridge, Minnesota, USA $(n=21)$; WI, Cedar Grove, Wisconsin, USA $(n=20)$; NJ, Cape May Point, New Jersey, USA $(n=21)$; PA, Little Gap, Pennsylvania, USA $(n=24)$; VA, Wise Point, Virginia, USA $(n=20)$; VC, La Mancha, Veracruz, Mexico $(n=20)$. + , Significant values $(P<0.05) ;-$, nonsignificant values.

\section{Historical demography}

Significant genetic differentiation between eastern and western groups led us to evaluate historical demography of the eastern and western regions separately. Mismatch distributions closely fit unimodal curves typically associated with recent population expansion (Fig. 5). These populations did not show a pattern associated with expectations of stationarity and their raggedness indices were low, as expected for populations under expansion in both the East $(r g=0.031, P<0.05)$ and the West $(r g=0.093, P<0.05)$.

The results for the various neutrality tests are summarized in Table 3. Fu's $F_{S}$ statistic was significant for both populations showing greater negative deviation in the West $\left(F_{\mathrm{S}}=-29.73, P<0.001\right)$ than in the East $\left(F_{\mathrm{S}}=-7.96\right.$, $P=0.006)$. Results for Fu's $F^{*}$ and $D^{*}$ were not statistically significant for either the western $\left(F^{*}=-2.27, P>0.05 ; D^{*}=\right.$ $-2.26, P>0.05)$ or the eastern population $\left(F^{*}=-2.10\right.$, $\left.P>0.05 ; D^{*}=-2.12, P>0.05\right)$. Tajima's $D$-values were significantly negative in the West $(D=-2.16, P=0.005)$, however, in the East Tajima's $D$, although negative, was not significantly different from zero $(D=-0.97, P=0.173)$. Finally, the expansion coefficients $(S / d)$ for both regions were found to have large values, with the value in the West $(S / d=28.95)$ being larger than that in the East $(S / d=9.87)$.
Estimates of time since expansion for each population were generated from the mismatch distributions resulting in a $\tau$ of 2.160 for eastern sites and 0.855 for western sites. Using a mutation rate of $14.8 \%$ per million years for domain I of the control region (Wenink et al. 1996; Merilä et al. 1997) and a generation time of two years for sharpshinned hawks (Bildstein \& Meyer 2000), time since expansion was estimated to be approximately 14000 вр for the eastern group and 5000 вр for the western group.

\section{Discussion}

The genetic data support a recent history of expansion of sharp-shinned hawks in North America. However, this study and others suggest that these migratory raptors appear to have an East-West continental distinction. Our analyses suggest that sharp-shinned hawks associated with these two regions were differentially affected by the climatic events during the Holocene.

\section{Population structure}

As expected based upon mark-recapture data, control region data for migratory sharp-shinned hawks support an east-west division among birds migrating through North 


\begin{tabular}{lccll}
\hline & East & West & $\begin{array}{l}\text { Expectation } \\
\text { Selection }\end{array}$ & Expansion \\
\hline Number of haplotypes & 20 & 24 & & \\
Nucleotide diversity & 0.00324 & 0.00140 & Low & Low \\
Haplotype diversity & 0.79 & 0.47 & Low & High \\
Expansion coefficient $(S / d)$ & 9.87 & 28.95 & & High \\
Tajima's (1989) $D$ & -0.968 & $-2.164^{*}$ & Significant & Significant \\
Fu \& Li's (1993) $F^{*}$ & -2.10 & -2.27 & Significant & Not significant \\
Fu \& Li's (1993) $D^{*}$ & -2.12 & -2.26 & Significant & Not significant \\
Fu's (1997) $F_{S}$ & $-7.96^{* *}$ & $-29.73^{* *}$ & Not significant & Significant \\
Raggedness $(r g)$ & $0.031^{*}$ & $0.093^{*}$ & & \\
$\tau$ & 2.160 & 0.855 & & \\
Time since expansion (years) & $c .14000$ & $c .5000$ & & \\
\hline
\end{tabular}

Table 3 Diversity, neutrality and expansion time estimates for migratory sharp-shinned hawks for eastern and western regions of North America from mitochondrial control region sequences

Expectations under mechanisms of selection or population expansion are given (Peck \& Congdon 2004). Significant values in the data are indicated with asterisks: ${ }^{*} P<0.05$; $* * P<0.01$.
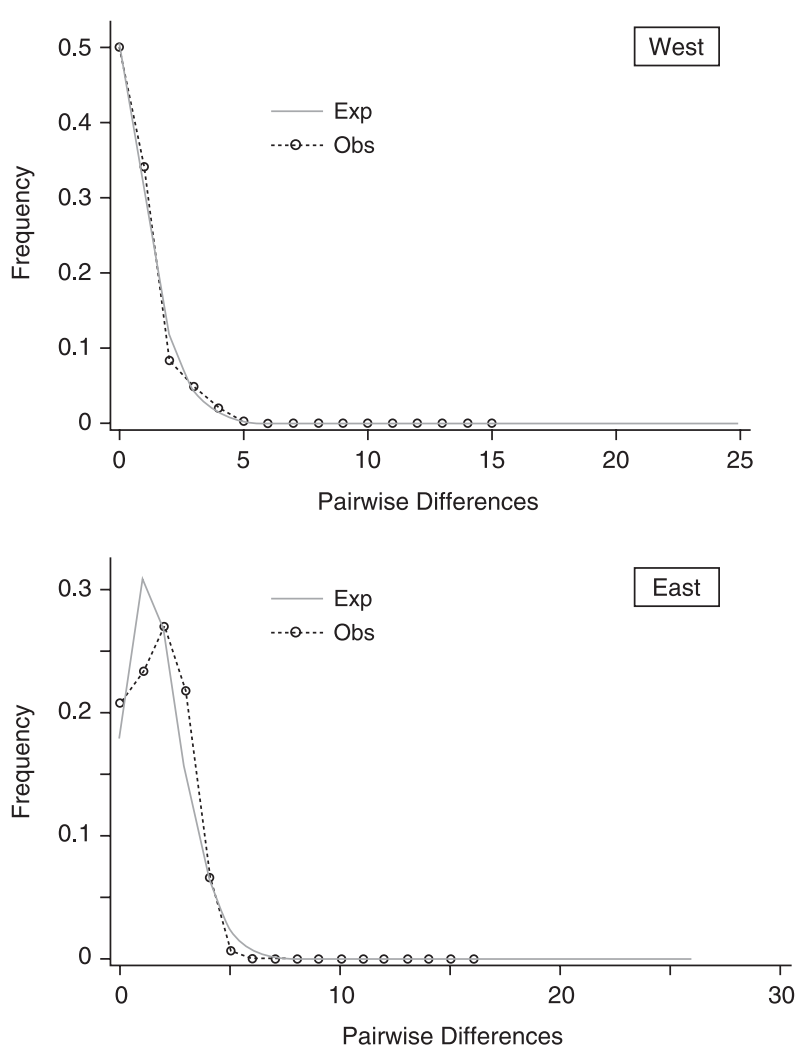

Fig. 5 Mismatch distributions for (a) western sampling localities and (b) eastern sampling localities: grey line, expected; dashed line with circles, observed.

America corresponding to areas separated by the Rocky Mountains and Great Plains. The western group was described by sampling sites along the Pacific coast and in the Great Basin (OR, CA, ID, NV and NM). The eastern group was composed of the Midwestern and Atlantic sampling sites (MN, WI, ON, NJ, VA, PN and VC). This grouping of samples appears to be most appropriate based upon the AMOVA results and the neighbour-joining tree of sampling sites, and correlates well with known band recovery data. Banding studies have found that individuals migrating through western migratory sites were strictly associated with putative western breeding populations and those caught travelling through eastern migratory sites were associated with eastern breeding sites (Clark 1985; Hoffman et al. 2002; Idaho Bird Observatory 2004). The eastwest division of genetic variation found in this study is consistent with previous studies of continental scale population structure in North American migratory birds (Milot et al. 2000; Kimura et al. 2002). Identification of eastern and western populations, along with previous band recovery data, may be of use to researchers at North American banding stations, and suggests that, although some straying may occur, the East and the West are generally behaving as two separate demographic units. Thus, perhaps population trends for eastern and western North America should be monitored and considered separately. Further examination of samples collected in breeding and wintering grounds will be important in the process of connecting the events being monitored at migration stations to endpoint locations.

\section{Population expansion}

The results from this study are consistent with those predicted under a scenario of population expansion of sharpshinned hawks in both the East and the West. However, the analyses show differences between the East and West indicating disparate demographic histories.

Statistical tests of neutrality provide strong support for the differential patterns of expansion in the eastern and western regions. Although various factors such as 
background selection, population growth and selective sweeps can account for deviations from neutrality, they can be distinguished from one another by evaluating the significance of different analyses. Fu's (1997) $F_{S}$ is particularly sensitive to population growth and selective sweeps relative to $\mathrm{Fu} \&$ Li's (1993) $D^{*}$ and $F^{*}$, whereas $D^{*}$ and $F^{*}$ are more sensitive to background selection than $F_{\mathrm{S}}$ (Fu 1997). Therefore, a pattern of significant $F_{\mathrm{S}}$ with nonsignificant $F^{*}$ and $D^{*}$ indicates population expansion or selective sweep and the opposite pattern would indicate effects of background selection (Peck \& Congdon 2004).

Our data support a pattern of population expansion showing significant negative values for $\mathrm{Fu}^{\prime} \mathrm{s} F_{\mathrm{S}}$ and nonsignificant values for $\mathrm{Fu}$ and Li's $D^{*}$ and $F^{*}$ (Table 3 ). In all cases the values associated with the western population were more negative, perhaps indicating a stronger expansion signal than that for the East. This association with population expansion was also supported by the mismatch distributions, which were not significantly different from the expectation of expansion, and had low levels of raggedness. A difference in the mismatch distributions in the West and the East is noticeable and may correspond to the differences in the pattern of expansion suggested by the neutrality tests described above. This difference is more keenly highlighted by the results of Tajima's $D$, which has been used to test for population expansion, but is known to be intermediate (between $\mathrm{Fu}^{\prime} \mathrm{s} F_{\mathrm{S}}$ and $\mathrm{Fu} \& \mathrm{Li}^{\prime} \mathrm{s} \mathrm{F}^{*}$ and $D^{*}$ ) in its sensitivity to population expansion (Tajima 1989; Congdon et al. 2000; Ramos-Onsins \& Rozas 2002). Tajima's $D$ was significantly negative in the West and was negative but nonsignificant in the East, suggesting a stronger signal for expansion in the West, which may suggest a more recent expansion event in the West relative to the East (Peck \& Congdon 2004). Although the results from the neutrality tests employed here can suggest either population expansion or selective sweeps, it would require additional data from independent nuclear loci to definitively distinguish between the two mechanisms. However, we know of no empirical evidence of selective sweeps in vertebrate mtDNA using comparisons of independent nuclear loci. Rather, we find an increasing prevalence of studies that report results indicating a signature of rapid expansion (Donnelly et al. 2001; Hahn et al. 2002).

Other indications of population expansion come from the pattern of a low level of nucleotide diversity and a high level of haplotype diversity. This was supported by large values of the expansion coefficient, which were greater than those found in other studies reporting population expansion (von Haeseler et al. 1996; Peck \& Congdon 2004). In addition, the parsimony tree, the neighbour-joining tree and the minimum spanning trees generated in this study display star-like patterns, which suggest a recent, rapid population expansion (Rogers 1995; Mila et al. 2000). This pattern is seen for sharp-shinned hawks as a whole, as well as for both the eastern and western populations individually, indicating each population has experienced rapid population growth.

Finally, we found a lower level of genetic variation within North American sharp-shinned hawk populations than has been previously found in North American Passerines. The cytochrome $b$ data for the Sharp-shinned hawks analysed revealed no sequence variation across the continent. This lack of variability was unexpected given the large geographical range sampled for $A$. s. velox and an estimated census population size of over one million (Ferguson-Lees \& Christie 2001).

Haplotype A was the most prevalent haplotype examined, forming an internal node in the minimum spanning tree that led to 19 terminal haplotypes, suggesting that this may be a progenitor haplotype in this species. Within $A$. s. velox in the West, haplotype A was found at all sites, comprised the majority of haplotypes sampled, and occupied an interior node of the minimum spanning tree. Haplotype A also appeared to be the immediate progenitor of the majority of haplotypes in the West. In the east, haplotype A was still prominent but haplotype $\mathrm{L}$ was also common and occupied another central node of the minimum spanning tree for the East. From these patterns it appears that haplotypes A (East and West) and L (East only) were widely distributed during the time of population expansions and may be progenitors of many of the other haplotypes seen with more restricted distributions among sites. Moreover, it suggests that the West and the East have different demographic histories.

\section{Climatic impacts on the history of sharp-shinned hawks in North America}

The timing of the recent population expansions in the east and west differed, with estimations of $14000 \mathrm{ybp}$ and $5000 \mathrm{ybp}$, respectively. While the accuracy of these estimates depends on the mutation rate, they suggest that the western group is considerably younger than the eastern group. The estimate associated with the eastern group is consistent with a response to glacial retreat from the last glacial maximum approximately (22 000-16 000 years ago (Webb \& Bartlein 1992; Eyles 1993). This pattern of population expansion is similar to postglacial population growth experienced by other bird species (Avise \& Walker 1998; Mila et al. 2000; Peck \& Congdon 2004).

There are two possible explanations for such a recent expansion of sharp-shinned hawks in the West. It is possible that the hawks were confined to eastern North America prior to about 5000 years ago and exhibited late growth from a single expanding population (see Zink et al. 2000) or that they were present in the West and then experienced a critical population decline. The fossil record for sharp-shinned hawks indicates they were present in larger numbers in the 
west 12000 years ago, following the last glacial cycle, and prior to 5000 years ago (Howard \& Miller 1933; Brodkorb 1964). Consequently, it appears that a significant event occurred roughly 5000 years ago resulting in either a severe reduction of the western population or total elimination of breeding sharp-shinned hawks in western North America.

Such a population reduction could conceivably have resulted from climatic events of the Hypsithermal, which reduced Sharp-shinned Hawk habitat along their migration route and within their breeding range. During this period, desert flora expanded in the North American south-west, replacing woodlands while seasonal droughts and fire frequency increased (Delcourt \& Delcourt 1993; Buck \& Curtis 1999; Carcaillet et al. 2001). Concurrent with western aridity, drought stress in the Pacific North-west breeding range resulted in development of forest communities with more open canopies such as Douglas fir and a decrease in prevalence of mesophytic conifers (Delcourt \& Delcourt 1993; MacDonald et al. 1993; Foley 1994; Davis 1999; Anderson et al. 2001). This shift in community structure could have greatly reduced both the foraging and nesting habitat of sharp-shinned hawks (Rosenfield et al. 1991).

Current paradigms of avian genetic structure and historical demography have been largely shaped by studies of North American songbird population structure and colonization patterns. However, Hypsithermal effects have not been reported in studies of North American songbird taxa examined to date. Patterns in these studies have typically been found to be concordant with interglacial expansions during the Pleistocene but have not demonstrated an influence of the Hypsithermal in the West (Mila et al. 2000; Milot et al. 2000; Kimura et al. 2002). In contrast to sharp-shinned hawks, songbird species studied previously, such as Wilson's warblers (Wilsonia pusilla), MacGillivray's warblers (Dendroica petechia), and yellow warblers (Oporornis tolmiei), have broader habitat tolerances (Bent 1953). Thus, loss of dense stands of conifer may not have resulted in a severe mid-Holocene population decline in these types of species.

The Hypsithermal has been implicated in range contraction in other organisms. Among avian species, low genetic variation in the Japanese rock ptarmigan (Lagopus mutus japonicas) appears to have been the result of a bottleneck during the Hypsithermal dry period caused by a decrease in Japanese stone pine (Pinus pumila) zone that is the required habitat of the Japanese rock ptarmigan (Yoshiyuki et al. 2001).

Climatic events during the Hypsithermal have also been implicated in altering population distribution of a variety of nonavian organisms. For example, Douglas et al. (2003) used molecular genetic evidence to suggest that population divergence in flannelmouth suckers (Catostomus latipinnis) may have resulted from drought conditions that peaked in the American west between $7000 \mathrm{ybp}$ and $4000 \mathrm{ybp}$.
Similarly, a study of the ringed salamander (Ambystoma annulatum) revealed low levels of genetic variation that may be the result of a recent range expansion following the climatic events and habitat changes during the Hypsithermal (Phillips et al. 2000). Finally, anthropological studies of Native American human populations suggest that humans abandoned dwellings in the Atacama desert during the Hypsithermal period (Nunez et al. 2002).

This study suggests that, species tied to dense forest habitats in western North America may have been differentially impacted by the Hypsithermal relative to their conspecifics in the East. However, it remains to be seen whether the Hypsithermal had a broad effect on North American raptor species in particular and/or whether the effect will be increasingly discovered across North American taxa requiring dense forest habitat.

\section{Acknowledgements}

We are grateful to the Golden Gate Raptor Observatory, Hawk Watch International, the Idaho Bird Observatory, Hawk Cliff Raptor Banding Station, Cedar Grove Raptor Banding Station, Little Gap Raptor Banding Station, Cape Charles Raptor Banding Station, Wise Point Raptor Banding Station, Hawk Ridge Raptor Banding Station, and Cape May Raptor Banding Inc. for assistance in sample collection, and also to the Yale Peabody Museum and U.C. Berkeley Museum of Vertebrate Zoology for loaning feather samples for genetic analysis. We thank the Golden Gate Raptor Observatory and the Sonoma State University Alumni Association for financial support. Thanks to A. Hull and A. Fish for contributions to collection protocols and study design, and B. Sacks and three anonymous reviewers for constructive comments.

\section{References}

Anderson L, Abbott MB, Finney BP (2001) Holocene climate inferred from oxygen isotope ratios in lake sediments, Central Brooks Range, Alaska. Quaternary Research (Orlando), 55, 313321.

Avise JC, Walker D (1998) Pleistocene phylogeographic effects on avian population and the speciation process. Proceedings of the Royal Society of London B: Biological Sciences, 265, 457-463.

Bent AC (1953) Life histories of North American wood warblers. United States National Museum Bulletin, 203, 743.

Bildstein KK, Meyer (2000) Accipiter striatus, Sharp-shinned Hawk. In: The Birds of North America, No. 482 (eds Poole A, Gill F). The American Ornithological Union, New York, NY.

Brodkorb P (1964) Catalogue of fossil birds: part 2 (Anseriformes through Galliformes). Bulletin of the Florida State Museum, 8, 195335.

Buck BJ, Curtis MH (1999) Stable isotopes and soil-geochemistry as indicators of Holocene climate change, northern Chihuahuan desert. Journal of Arid Environments, 43, 357-373.

Carcaillet C, Bergeron Y, Richard Pierre JH, Frechette B, Gauthier S, Prairie YT (2001) Change in fire frequency in the eastern Canadian boreal forests during the Holocene. Does vegetation composition or climate trigger the fire regime? Journal of Ecology, 89, 930-946. 
Clark WS (1985) The migrating Sharp-shinned Hawk at Cape May Point: banding recovery results. In: Proceedings of Hawk Migration Conference IV (ed. Harwood M), pp. 137-148. The Hawk Migration Association of North America, New York, NY.

Congdon BC, Platt JF, Martin K, Friesen V (2000) Mechanisms of population differentiation in marbled murrelets: historical vs. contemporary processes. Evolution, 54, 974-986.

Davis MB (1969) Climatic changes in southern Connecticut recorded by pollen deposition at Rogers Lake. Ecology, 50, 409422.

Davis OK (1999) Pollen analysis of Tulare Lake, California: Great Basin-like vegetation in central California during the full-glacial and early Holocene. Review of Paleobotany and Palynology, 107, 249-257.

Delcourt PA, Delcourt HR (1993) Paleoclimates, paleovegetation, and paleofloras of North America north of Mexico during the late Quaternary. In: Flora of North America North of Mexico (eds Flora of North North America Editorial Committee), pp. 71-94. Oxford University Press, New York, NY.

Donnelly MJ, Licht MC, Lehmann T (2001) Evidence for recent population expansion in the evolutionary history of the malaria vectors Anopheles arabiensis and Anopholes gambiae. Molecular Biology and Evolution, 18, 1353-1364.

Douglas MR, Brunner PC, Douglas ME (2003) Drought in an evolutionary context: molecular variability in Flannelmouth Sucker (Catostomus latipinnis) from the Colorado River basin of western North America. Freshwater Biology, 48, 1254-1273.

Excoffier L, Smouse PE, Quattro JM (1992) Analysis of molecular variance inferred from metric distances among DNA haplotypes: application to human mitochondrial DNA restriction data. Genetics, 131, 479-494.

Eyles N (1993) Earth's glacial record and its tectonic setting. Earth Science Reviews, 35, 1-248.

Felsenstein J (1989) PHYLIP - Phylogenetic Inference Package, Version 3.2. University of Washington, Seattle, WA.

Ferguson-Lees J, Christie DA (2001) Raptors of the World. Houghton Mifflin Company, New York, NY.

Foley JA (1994) The sensitivity of the terrestrial biosphere to climate change: a simulation of the Middle Holocene. Global Biogeochemical Cycles, 8, 505-525.

$\mathrm{Fu} \mathrm{Y} \mathrm{(1997)} \mathrm{Statistical} \mathrm{tests} \mathrm{of} \mathrm{neutrality} \mathrm{of} \mathrm{mutations} \mathrm{against}$ population growth, hitchhiking, and background selection. Genetics, 147, 915-925.

$\mathrm{Fu} \mathrm{Y,} \mathrm{Li} \mathrm{WH} \mathrm{(1993)} \mathrm{Statistical} \mathrm{tests} \mathrm{of} \mathrm{neutrality} \mathrm{of} \mathrm{mutations.}$ Genetics, 133, 693-709.

von Haeseler A, Sajantila A, Paabo S (1996) The genetical archaeology of the human genome. Nature Genetics, 14, 135-140.

Hahn MW, Rausher MD, Cunningham CW (2002) Distinguishing between selection and population expansion in an experimental lineage of bacteriophage T7. Genetics, 161, 11-20.

Haring E, Kruckenhauser L, Gamauf A, Riesing MJ, Pinsker W (2001) The complete sequence of the mitochondrial genome of Buteo buteo (Aves, Accipitriidae) indicates an early split in the phylogeny of raptors. Molecular Biology and Evolution, 18, 18921904.

Harpending HC, Sherry ST, Rogers AR, Stoneking M (1993) The genetic structure of human populations. Current Anthropology, 34, 483-496.

Hoffman SW, Smith JP, Meehan TD (2002) Breeding grounds, winter ranges, and migratory routes of raptors in the mountain west. Journal of Raptor Research, 36, 97-110.
Howard H, Miller AH (1933) Bird remains from cave deposits in New Mexico. Condor, 35, 16-20.

Hudson RR, Slatkin M, Maddison WP (1992) Estimation of levels of gene flow from DNA sequences. Genetics, 132, 583-589.

Hull B (2003) Stretching the southern limits. Pacific Raptor Report, 24, 16-23.

Idaho Bird Observatory (June 2004) Raptor monitoring web site. http://www.boisestate.edu/biology/ibo/raptor.html

Kidd MG, Friesen VL (1998) Analysis of mechanisms of microevolutionary change in Cepphus guillemots using patterns of control region variation. Evolution, 52, 1158-1168.

Kimura M, Clegg SM, Lovette IJ, Holder KR, Girman DJ, Mila B, Wade P, Smith TB (2002) Phylogenetic approaches to assessing demographic connectivity between breeding and overwintering regions in a Nearctic-Neotropical warbler (Wilsonia pusilla). Molecular Ecology, 7, 1605-1616.

Klicka J, Zink RM (1997) The Importance of recent ice ages in speciation: a failed paradigm. Science, 277, 1666-1669.

MacDonald GM, Edwards TWD, Moser KA, Pienitz R, Smol JP (1993) Rapid response of treeline vegetation and lakes to past climate warming. Nature, 361, 243-246.

Merilä J, Björklund M, Baker AJ (1997) Historical demography and present day population structure of the greenfinch, Carduelis chloris - an analysis of mtDNA control-region sequences. Evolution, 51, 946-956.

Mila B, Girman DJ, Kimura M, Smith TB (2000) Genetic evidence for the effect of a postglacial population expansion on the phylogeography of a North American songbird. Proceedings of the Royal Society of London B: Biological Sciences, 267, 1033-1040.

Milot E, Gibbs HL, Hobson KA (2000) Phylogeography and genetic structure of northern populations of the yellow warbler (Dendroica petechia). Molecular Ecology, 9, 667-681.

Nei M (1987) Molecular Evolutionary Genetics. Columbia University Press, New York, NY.

Newton I (1979) Population Ecology of Raptors. Buteo Books, Vermillion, SD.

Nunez L, Grosjean M, Cartajena I (2002) Human occupations and climate in the Puna de Atacama, Chile. Science, 298, 821824.

Outlaw DC, Voelker G, Mila B, Girman DJ (2003) The evolution of long distance migration in and historical biogeography of the Catharus thrushes: a molecular phylogenetic approach. Auk, 120, 299-310.

Peck DR, Congdon BC (2004) Reconciling historical processes and population structure in the sooty tern Sterna fuscata. Journal of Avian Biology, 35, 327-335.

Phillips CA, Saua G, Templeton AR (2000) Effects of Holocene climate fluctuation on mitochondrial DNA variation in the ringed salamander, Ambystoma annulatum. Copeia, 2000, 542545.

Ramos-Onsins S, Rozas J (2002) Statistical properties of new neutrality tests against population growth. Molecular Biology and Evolution, 19, 2092-2100.

Rogers AR (1995) Genetic evidence for a Pleistocene population explosion. Evolution, 49, 608-615.

Rogers AR, Harpending H (1992) Population growth makes waves in the distribution of pairwise genetic differences. Molecular Biology and Evolution, 9, 552-569.

Rosenfield RNJ, Bielefeldt RK, Anderson JM, Papp (1991) Status reports: accipiters. In: Proceedings of the Midwest Raptor Management Symposium and Workshop (ed. Pendleton BG). National Wildlife Federation, Washington, DC, 42-49. 
Rozas J, Sánchez-De JC, Barrio I, Messeguer X, Rozas R (2003) DnaSP, DNA polymorphism analyses by the coalescent and other methods. Bioinformatics, 19, 2496-2497.

Saiki RK, Gelfand DH, Stoffel S (1980) Primer directed enzymatic amplification of DNA with a thermostable DNA polymerase. Science, 239, 487-491.

Schneider S, Kueffer J, Roessli D, Excoffier L (1997) ARLEQUIN: a Software for Population Genetic Data Analysis, 1.1. Genetics and Biometry Laboratory. University of Geneva, Geneva.

Sibley CG, Ahlquist JE (1991) Phylogeny and Classification of Birds: a Study in Molecular Evolution. Yale University Press, New Haven, CT.

Sorenson MD, Ast JC, Dimcheff DE, Yuri T, Mindell DP (1999) Primers for a PCR-based approach to mitochondrial genome sequencing in birds and other vertebrates. Molecular Phylogenetics and Evolution, 12, 105-114.

Steig EJ (1999) Mid-Holocene climate change. Science, 286, 1485 1486.

Swofford DL (2003) PAUP 4.0 beta version for the Macintosh PowerPC - Phylogenetic Analysis Using Parsimony (and Other Methods). Sinauer Associates, New York, NY.

Tajima F (1989) Statistical method for testing the neutral mutation hypothesis by DNA polymorphism. Genetics, 123, 585-595.

Takahata N, Palumbi SR (1985) Extranuclear differentiation and gene flow in the finite island model. Genetics, 109, 441-457.

Tamura K, Nei M (1993) Estimation of the number of nucleotide substitutions in the control region of mitochondrial DNA in humans and chimpanzees. Molecular Biology and Evolution, 10, 512-526.
Wattel J (1973) Geographic Differentiation in the Genus. Accipiter. Nuttall Ornithological Club, Cambridge, MA.

Webb SD (1984) Ten million years of mammal extinctions in North America. In: Quaternary Extinctions (eds Martin PS, Klein RG), pp. 189-210. University of Arizona, Tucson, AZ.

Webb TI, Bartlein P (1992) Global changes during the last 3 million years: climatic controls and biotic responses. Annual Review of Ecology and Systematics, 23, 141-173.

Wenink PW, Baker AJ, Rosner HU, Tilanus MGJ (1996) Global mitochondrial DNA phylogeny of holoarctic breeding dunlins (Calidris alpina). Evolution, 50, 318-330.

Yoshiyuki B, Yuzo F, Ryoichi Y, Hiroko K (2001) Genetic variability in the mitochondrial control region of the Japanese rock ptarmigan, Lagopus mutus japonicus. Japanese Journal of Ornithology, 50, 5364.

Zink RM, Barrowclough GF, Atwood JL, Blackwell-Rago RC (2000) Genetics, taxonomy, and conservation of the threatened California gnatcatcher. Conservation Biology, 14, 1394-1405.

This research was part of Joshua Hull's Master's Thesis research project at Sonoma State University. Mr. Hull continues to study raptors in his $\mathrm{PhD}$ research with the Wildlife Genetics Unit at the University of California, Davis. Derek Girman's research group works in the areas of conservation genetics and molecular systematics focusing on questions related to population structure and genetic diversity, historical demography, biogeography, speciation, and the origin of phenotypic traits. 